\title{
Notes on the vocalizations of Long-billed Lark complex (genus Certhilauda)
}

\section{Peter Boesman}

In the following we briefly analyze and compare voice of the different races of the Longbilled Lark complex (genus Certhilauda). We also try to quantify the extent of any vocal differences using the criteria proposed by Tobias et al. (2010), as a support for taxonomic review. We have made use of sound recordings available on-line from Xeno Canto (XC) and Macaulay Library (ML).

Song during display flight of all members of the Long-billed Lark complex is a drawn-out slightly descending pure whistle (preceded by an intro note which may be very weak). Some examples per taxon:

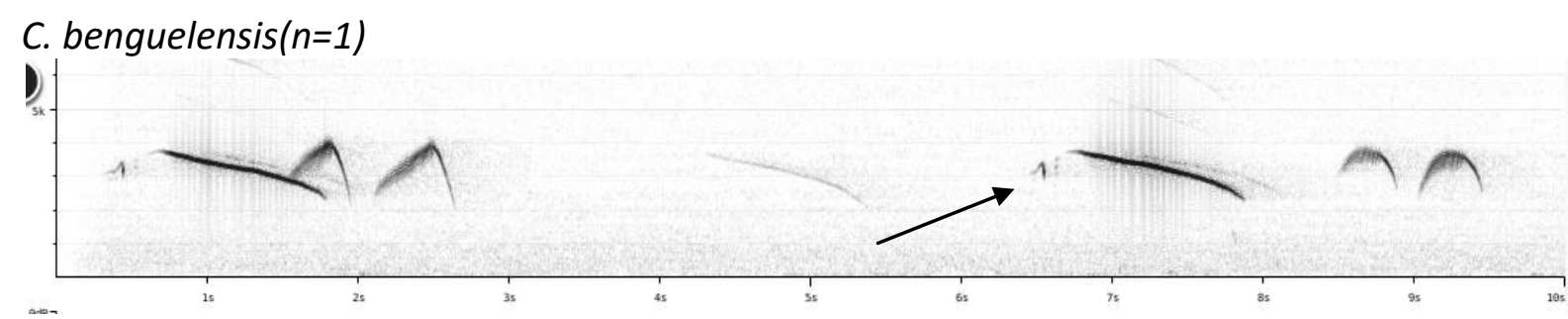

\section{C. subcoronata}

(damarensis)
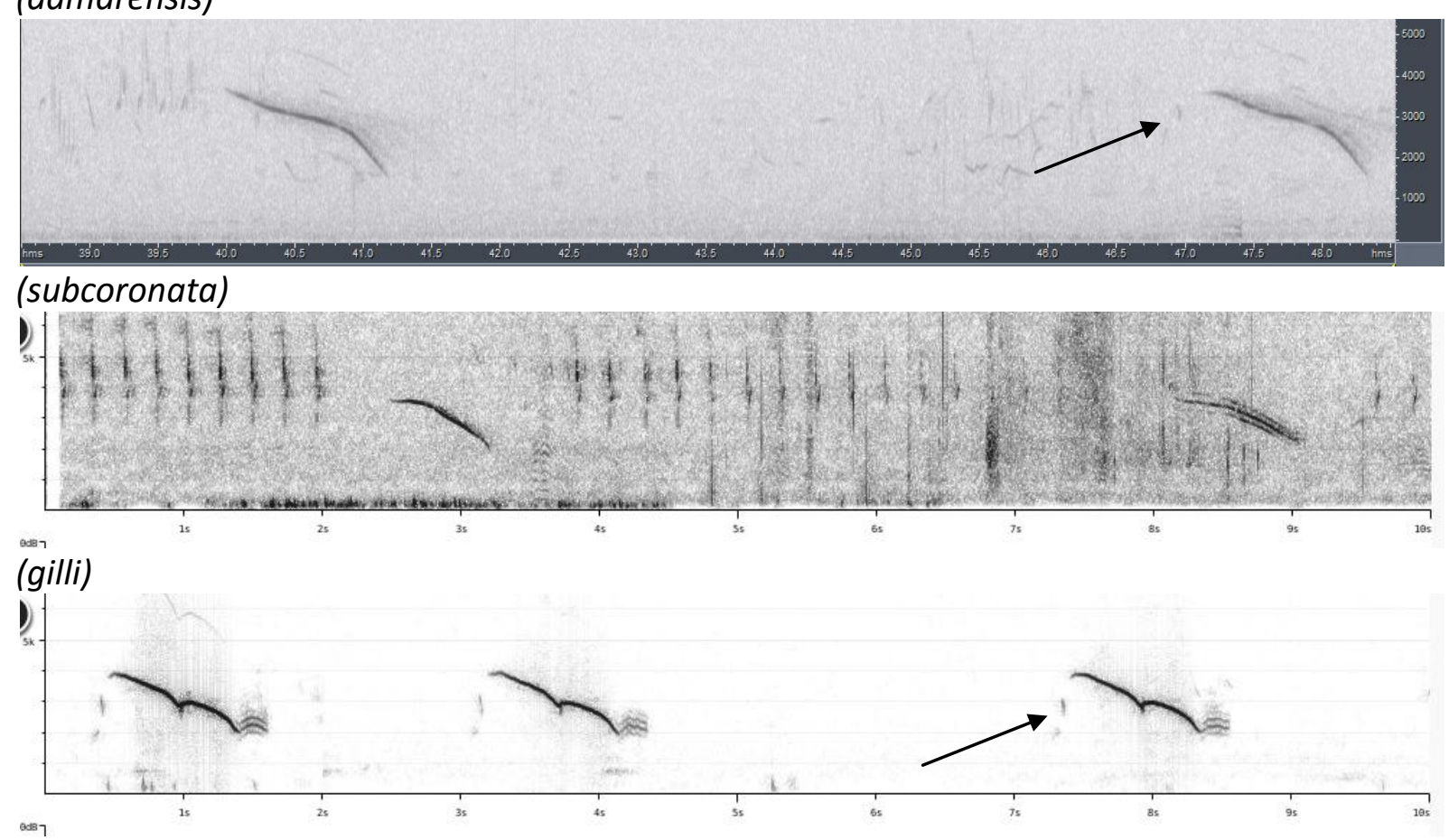


\section{C. curvirostris}

Intro note becomes longer and longer towards the south, becoming about identical to $C$. brevirostris!
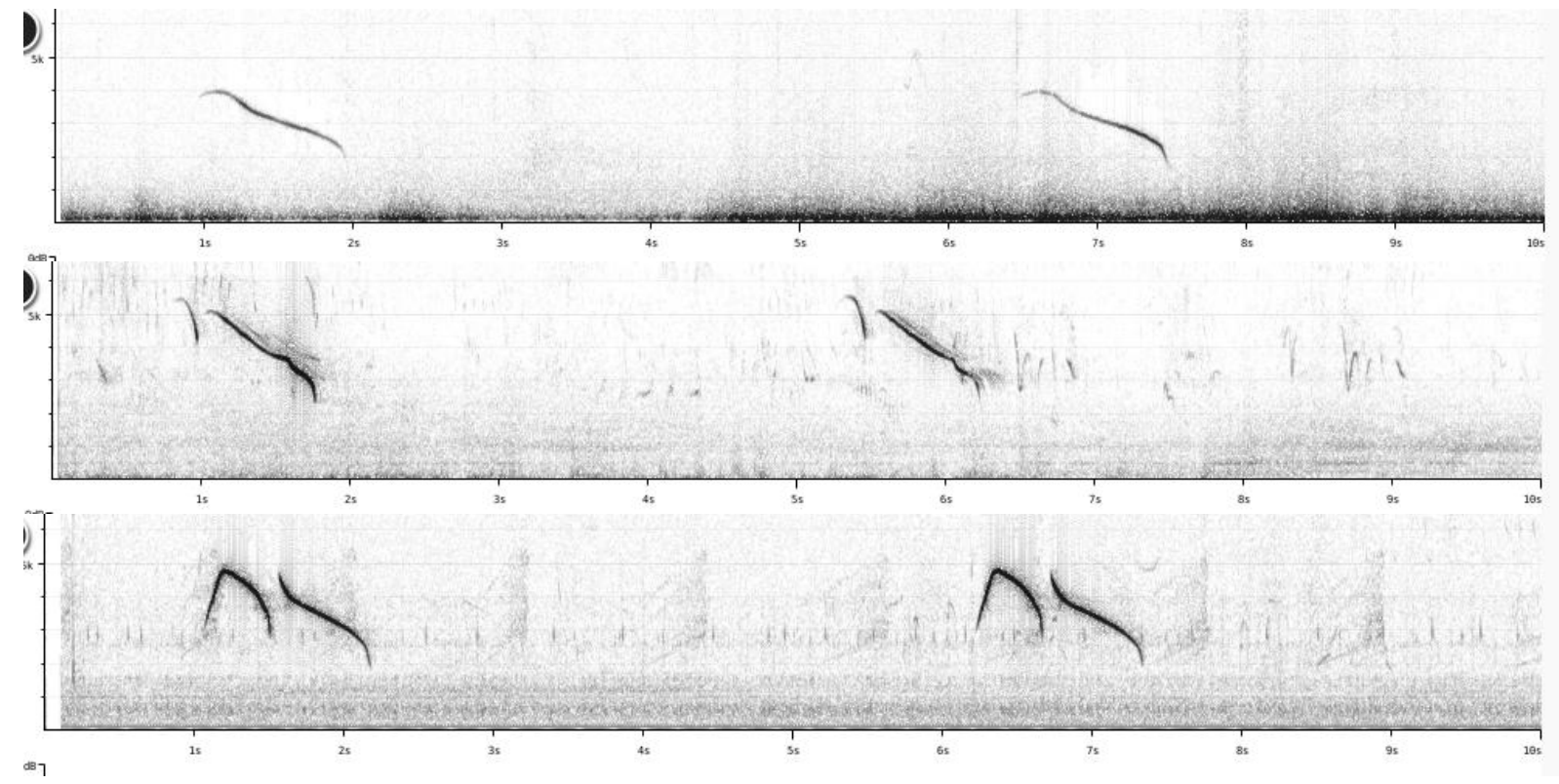

C. brevirostris
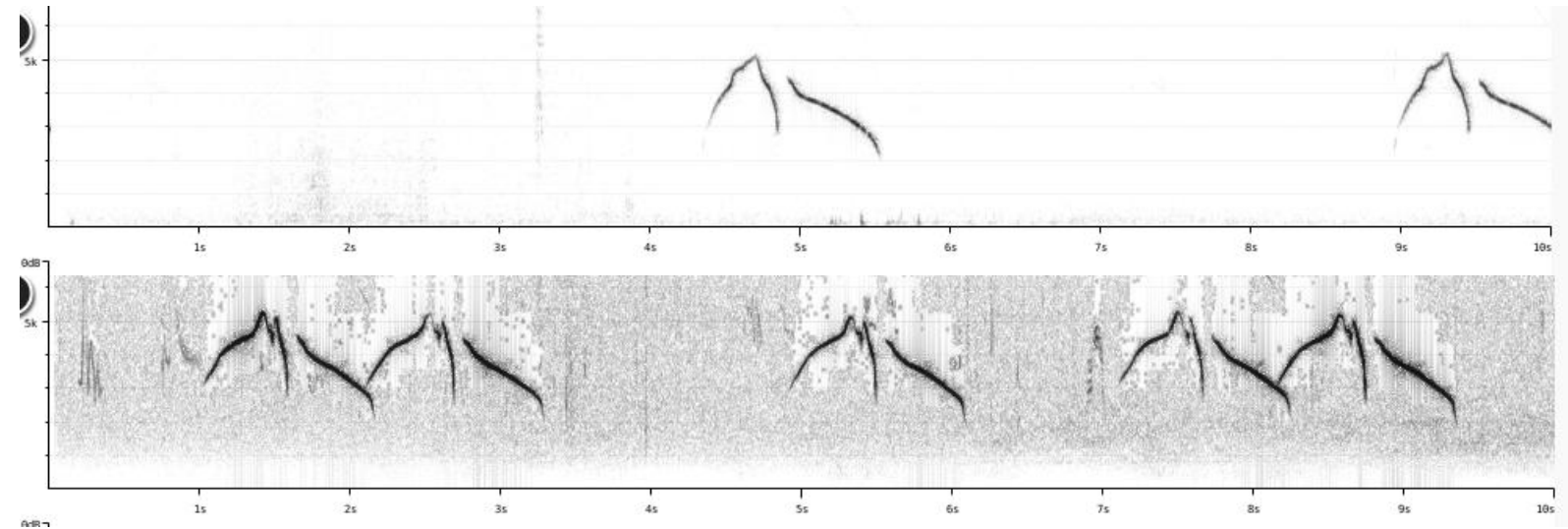

\section{C. semitorquata}

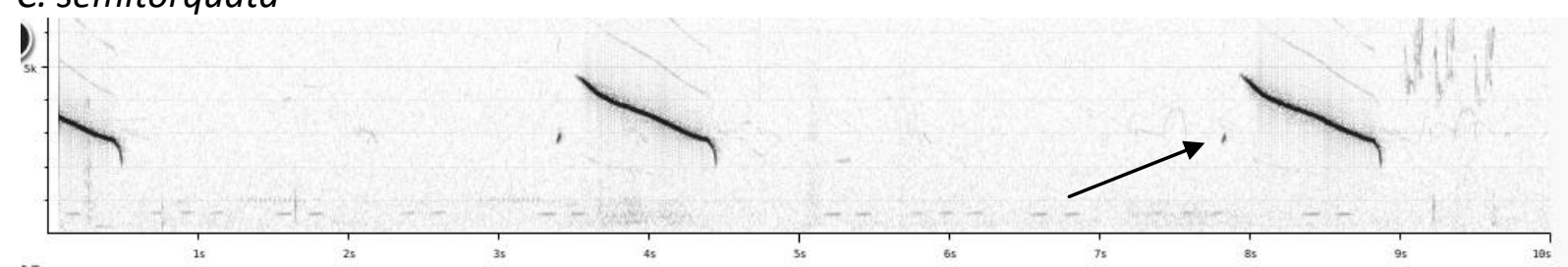

It is clear from the above that song is of little help to support present breakdown in species. With many more samples, possibly slight but consistent differences may be detected in slope of whistle etc., but these differences will be very subtle at most, and will not lead to important scores for vocal difference.

Call notes may be another path to investigate, but not many recordings are presently available, and at first sight these are also quite similar. 
This note was finalized on 5th February 2016, using sound recordings available on-line at that moment. We would like to thank in particular the sound recordists who placed their recordings for this species on XC and ML: Peter Boesman, Sander Bot, Franck Bruneliere, Allen Collett, Daniel Danckwerts, Dawie de Swardt, Charles Hesse, Don Jones, Ethan Kistler, Catriona Leven, Linda Macaulay, Niall Perrins, Lynette Rudman, Andrew Spencer, Rob van Bemmelen and David Winter.

\section{References}

Tobias, J.A., Seddon, N., Spottiswoode, C.N., Pilgrim, J.D., Fishpool, L.D.C. \& Collar, N.J. (2010). Quantitative criteria for species delimitation. Ibis 152(4): 724-746.

\section{Recommended citation}

Boesman, P. (2016). Notes on the vocalizations of the Long-billed Lark complex (genus Certhilauda). HBW Alive Ornithological Note 218. In: Handbook of the Birds of the World Alive. Lynx Edicions, Barcelona. (retrieved from http://www.hbw.com/node/932176 on 6 September 2016). 